\title{
EVALUASI IMPLEMENTASI PARADIGMA BARU PENDIDIKAN PASCAREFORMASI PADA JENJANG SD DI KOTA SALATIGA
}

\author{
${ }^{1)}$ Wasitohadi, ${ }^{2)}$ F.X. Sudarsono, ${ }^{3)}$ Zamroni \\ ${ }^{1)}$ Universitas Kristen Satya Wacana, ${ }^{2,3)}$ Universitas Negeri Yogyakarta \\ 1)adi_wasito02@yahoo.co.id, ${ }^{3)}$ zamronihardjowirono@yahoo.com
}

\begin{abstract}
Abstrak
Penelitian ini bertujuan untuk mengetahui dampak paradigma baru pendidikan terhadap sistem dan praksis pendidikan SD di Salatiga, difokuskan pada implementasi paradigma baru pendidikan dan rasionalnya. Jenis penelitian yang digunakan adalah penelitian evaluasi kebijakan. Penelitian menggunakan pendekatan kualitatif dan kuantitatif. Data kualitatif diperoleh dari informaninforman kunci serta berbagai dokumen terkait melalui studi dokumen, observasi, wawancara, dan angket. Data yang terkumpul dianalisis secara kualitatif dengan menggunakan pendekatan induktif, sedangkan data kuantitatif digunakan sebagai suplement dan complement yang bersifat mendukung atau memperjelas data kualitatif. Hasil penelitian menunjukkan bahwa paradigma baru pendidikan berdampak terhadap sistem dan praksis pendidikan SD. Sistem pendidikan yang dibuat telah mengalami perubahan sesuai dengan paradigma baru pendidikan. Namun, karena pola pikir (mindset) stakeholders belum berubah, maka praksis pendidikan pada ketiga aspek yang menjadi fokus penelitian (peran kepala sekolah, peningkatan profesionalitas guru, dan proses pembelajaran) belum sepenuhnya sesuai seperti yang diharapkan dalam kebijakan. Optimalisasi peran kepala sekolah dan peningkatan profesionalitas guru menjadi prioritas untuk dilakukan.
\end{abstract}

Kata kunci: paradigma baru pendidikan, sistem pendidikan, praksis pendidikan, peran kepala sekolah, peningkatan profesionalitas guru, proses pembelajaran.

\section{EVALUATION OF THE IMPLEMENTATION OF A NEW POST-REFORMATION EDUCATIONAL PARADIGM IN PRIMARY SCHOOLS IN SALATIGA}

\author{
${ }^{1)}$ Wasitohadi, ${ }^{2)}$ F.X. Sudarsono, ${ }^{3)}$ Zamroni \\ ${ }^{1)}$ Universitas Kristen Satya Wacana, ${ }^{2,3}$ Universitas Negeri Yogyakarta \\ 1) adi_wasito02@yahoo.co.id, ${ }^{3)}$ zamronihardjowirono@yahoo.com
}

\begin{abstract}
The purpose of this research is to find the effect of new educational paradigm on primary schools system and praxis in Salatiga, focusing on the implementation of new educational paradigm and its rationale. The research was limited on the aspects of school principal's role, teacher professional enhancement, and learning process. The type of the research was policy evaluation research. The research approach was qualitative and quantitative. The qualitative data were collected from key informants and various related documents through documents study, observation, interview, and questionnaire. The collected data were then analyzed qualitatively as inductive data. Quantitative data were used as supplement and complement to support or clarify qualitative data. The research found that new educational paradigm impacted on the system and praxis in elementary education. Implementation of education system related to the three aspects had changed according to the new educational paradigm. However, because the stakeholder's mindset had not changed, education praxis was not fully appropriate for what was expected in the policy. Thus, optimizing school principal's roles and enhancing teacher professionalism became the priority to be done.
\end{abstract}

Keywords: new educational paradigm, education system, education praxis, school principal's role, teacher professional enhancement, learning process 


\section{PENDAHULUAN}

Salah satu kebijakan pendidikanpasca reformasi adalah melakukan pembaharuan dan pemantapan sistem pendidikan nasional berdasarkan prinsip desentralisasi, otonomi keilmuan dan manajemen (GBHN, 1999). Adanya kebijakan ini mengisyaratkan bahwa dimungkinkan adanya pembaharuan dan pemantapan sistem pendidikan nasional. Dalam rangka memperbaharui dan memantapkan sistem pendidikan nasional tersebut, pencarian paradigma baru pendidikan merupakan upaya yang mendesak untuk pelaksanaan kebijakan dan praktek pendidikan di Indonesia (Sudarsono, 1999, p.1).

Gagasan perlunya paradigma baru pendidikan dilatarbelakangi oleh sejumlah faktor. Selain karena akumulasi dampak kebijakan pendidikan masa lalu, juga disebabkan oleh tantangan dan kebutuhan global serta menguatnya tuntutan gerakan reformasi di Indonesia (Tilaar, 2004, p.2) Gerakan reformasi di Indonesia menuntut diterapkannya prinsip demokrasi, desentralisasi, keadilan, dan menjunjung tinggi hak asasi manusia dalam kehidupan berbangsa dan bernegara (Undang-Undang Nomor 20, 2003). Gerakan tersebut telah menumbuhkan kesadaran akan hak otonomi bagi daerah, yang lalu menumbuhkan pemikiran tentang perlunya penerapan sistem desentralisasi pendidikan. Tentu saja, penerapan sistem tersebut mempunyai konsekuensi-konsekuensi yang mendasar dalam penyelenggaraan pendidikan. Salah satunya adalah perubahan pada manajemen pendidikan, dari berbasis pusat menjadi berbasis daerah.

Dengan kata lain, manajemen pendidikan harus disesuaikan dengan jiwa dan semangat otonomi. Dalam era otonomi, daerah diberi tanggung jawab yang semakin besar untuk mengatur dan melaksanakan kewenangannya di bidang pendidikan atas prakarsa sendiri. Sementara itu, ada tuntutan agar manajemen pendidikan didasarkan pada prinsipprinsip demokrasi, peran serta masyarakat, pemerataan, keadilan, dan memperhatikan potensi serta keanekaragaman daerah. Karena itu, penyesuaian tersebut juga menuntut adanya perubahan/pergeseran paradigma pendidikan, dari paradigma lama ke paradigma baru pendidikan. Mengenai perubahan/ pergeseran paradigma tersebut, dalam UU Nomor 20 Tahun 2003 tentang Sistem Pendidikan Nasional, disebutkan sebagai berikut.
(1) Pendidikan diselenggarakan secara demokratis dan berkeadilan serta tidak diskriminatif dengan menjunjung tinggi hak asasi manusia, nilai keagamaan, nilai kultural, dan kemajemukan bangsa.

(2) Pendidikan diselenggarakan sebagai satu kesatuan yang sistemik dengan sistem terbuka dan multimakna.

(3) Pendidikan diselenggarakan sebagai suatu proses pembudayaan dan pemberdayaan peserta didik yang berlangsung sepanjang hayat.

(4) Pendidikan diselenggarakan dengan memberi keteladanan, membangun kemauan, dan mengembangkan kreativitas peserta didik dalam proses pembelajaran.

(5) Pendidikan diselenggarakan dengan mengembangkan budaya membaca, menulis, dan berhitung bagi segenap warga masyarakat.

(6) Pendidikan diselenggarakan dengan memberdayakan semua komponen ma-syarakat melalui peran serta dalam penyelenggaraan dan pengendalian mutu layanan pendidikan.

Dari prinsip-prinsip ini, tampak bahwa telah terjadi perubahan paradigma pendidikan dalam sistem pendidikan nasional. Hal ini terlihat dari prinsip penyelenggaraan pendidikan yang jauh lebih demokratis dan berorientasi pada teori dan praksis pendidikan yang semakin mengedepankan nilai-nilai demokrasi dan nilai-nilai global-universal. Selanjutnya, penjelasan UU tersebut menegaskan bahwa dalam hubungannya dengan pendidikan, prinsip-prinsip tersebut akan memberikan dampak yang mendasar pada kandungan, proses, dan manajemen sistem pendidikan. Sejalan dengan perubahan para-digma pendidikan tersebut, maka kandungan, proses, dan manajemen sistem pendidikan juga mengalami perubahan atau pembaharuan.

Secara ideal, berlakunya paradigma baru pendidikan tersebut akan mewarnai dan berdampak positif terhadap sistem dan praksis penyelenggaraan pendidikan. Sistem manajemen pendidikan mulai dari proses perumusan kebijakan, penyusunan program, hingga praksis penyelenggaraan pendidikannya, baik di tingkat pusat, daerah maupun satuan pendidikan, mestinya merupakan penerapan dari paradigma baru pendidikan tersebut. Dengan demikian, penerapan paradigma baru 
pendidikan diasumsikan dapat berdampak positif bagi kemajuan pendidikan di daerah.

Data empirik berbagai pengalaman internasional di beberapa negara menunjukkan bahwa kebijakan desentralisasi pendidikan berdampak positif pada: (1) peningkatan mutu, (2) efisiensi administrasi, (3) efisiensi keuangan, dan (4) perluasan dan pemerataan pendidikan (Fiske, 1998, p.48; Amich Alhumani, Kompas, 11 September 2000). Namun, dalam kenyataan tidak selalu demikian. Bank Dunia (1998, p.73) mengingatkan: "Clearly, decentralization is not an answer to all education problems, but experience shows that it is a necessary, while not a sufficient, condition for improving teaching and learning". Desentralisasi pendidikan juga menimbulkan banyak masalah (Fiske, 1998) dan bukan satusatunya alternatif terbaik untuk memperbaiki kualitas pendidikan (Hadiyanto, 2004, p.64), tidak semua negara yang menerapkan berhasil seperti yang diteorikan (Dedi Supriadi, 2003), bahkan praksis pendidikan justru mengalami reduksionisme (Winarno Surakhmad, 2009, p.467), sedangkan proses pengembangan penalaran, inovasi, imajinasi, dan moral tidak terjadi (Sudarsono, 1999, p.1).

Terlepas dari adanya pro dan kontra tersebut, realitas menunjukkan bahwa implementasi kebijakan pendidikan di Indonesia selama ini memberi dampak yang beragam. Implementasi kebijakan pemerataan dan perluasan akses pendidikan, misalnya, telah berdampak pada peningkatan pencapaian angka partisipasi pendidikan secara sangat meyakinkan di semua jenjang, namun belum diukur dengan indikator mutu penguasaan kompetensi dasar (Depdiknas, 2007). Sementara itu, untuk implementasi kebijakan peningkatan mutu pendidikan, hasil dan dampaknya masih memprihatinkan, tercermin dari hasil kajian berbagai institusi baik secara makro maupun mikro (Kompas, 10 Desember 2007). Mengapa hal ini bisa terjadi?Ada banyak sebab, salah satunya karena masih banyak terjadi kelambanan dan kerancuan perubahan cara berfikir dari pola sentralistik ke desentralistik. Paradigma baru pendidikan sebagai paradigma berfikir manajemen pola desentralistik diduga belum mewarnai sistem dan praksis pendidikan di tingkat lokal dan satuan pendidikan.

Dari deskripsi tersebut, perlu dilakukan penelitian mengenai dampak paradigma baru pendidikan terhadap sistem dan praksis pendidikan di tingkat lokal. Peneliti membatasi pada pelaksanaan pendidikan di SD, difokuskan pada implementasi paradigma baru pendidikan dan rasionalnya. Dalam hal ini, penelitian dibatasi pada sistem dan praksis pendidikan SD, difokuskan pada implementasi paradigma baru pendidikan dan rasionalnya. Peneliti memusatkan pada aspek peran kepala sekolah, peningkatan profesionalitas guru, dan proses pembelajaran. Argumentasinya, kepala sekolah dan guru sebagai sumber daya manusia bersifat sangat menentukan, bahkan guru khususnya merupakan ujung tombak peningkatan mutu. Sedangkan proses pembelajaran di sekolah merupakan inti pendidikan, sehingga perbaikan kualitasnya harus menjadi prioritas perhatian. Dengan demikian, paradigma baru, sistem dan praksis pendidikan dalam penelitian ini menunjuk pada paradigma baru, sistem dan praksis pendidikan SD di Salatiga dalam upaya melaksanakan kebijakan peningkatan mutu sekolah menyangkut aspek-aspek sistem pendidikan SD di atas.

Dipilihnya Kota Salatiga didasarkan pada beberapa alasan. Pertama, sudah sejak lama Kota Salatiga diarahkan sebagai kota pendidikan. Ini berarti, telah ada kesadaran akan pentingnya pendidikan sebagai strategi untuk mengembangkan Kota Salatiga. Kedua, potensi sosial yang dimiliki Kota Salatiga. Wilayah Salatiga relatif sempit, sehingga memperpendek rentang kendali pengelolaan yang dapat memudahkan penyelenggaraan pendidikan. Dengan lokasi pegunungan berhawa sejuk, dan pola hidup masyarakatnya yang belum terlalu metropolis, juga akan sangat menopang bagi terselenggarakannya proses pendidikan yang bermutu. Selain itu, tradisi akademis juga relatif mapan. Beberapa lembaga pendidikan sudah hidup, mampu bertahan dan bahkan berkembang selama puluhan tahun. Dengan watak akademis seperti itu merupakan fondasi kokoh bagi upaya peningkatan mutu pendidikan. Dan ketiga, sama seperti daerah lain, Kota Salatiga jelas terkena dampak perubahan paradigma baru pendidikan, sehingga layak dikaji, dalam rangka memahami permasalahannya untuk menemukan solusinya.

Sementara itu, dipilihnya jenjang SD karena pendidikan SD memiliki kedudukan yang strategis bagi peningkatan kualitas 
manusia Indonesia, sehingga menuntut dikelolanya pendidikan tersebut secara profesional agar dapat menjadi tumpuan bagi pengembangan manusia Indonesia selanjutnya.

Berdasarkan uraian tersebut, masalah penelitian ini adalah:

1. Apa peran kepala sekolah dalam paradigma baru pendidikan pascareformasi untuk peningkatan mutu pendidikan di SD? Benarkah dengan berlakunya paradigma baru pendidikan pascareformasi, peran kepala sekolah mengalami perubahan, lalu apa dampaknya bagi pendidikan SD?

2. Bagaimana peningkatan profesionalitas guru dalam konteks berlakunya paradigma baru pendidikan pascareformasi? Benarkah peningkatan profesionalitas guru mengalami perubahan dengan berlakunya paradigma baru pendidikan, lalu apa dampaknya bagi pendidikan SD?

3. Bagaimanakah proses pembelajaran di SDSD tempat penelitian berlangsung dalam konteks berlakunya paradigma baru pendidikan pascareformasi? Apakah dengan berlakunya paradigma baru pendidikan, proses pembelajaran tersebut mengalami perubahan dan peningkatan, lalu apa dampaknya bagi pendidikan SD?

\section{METODE PENELITIAN}

Jenis penelitian yang digunakan adalah penelitian evaluasi kebijakan. Dalam penelitian evaluasi kebijakan terkandung adanya kriteria yang dipakai untuk menentukan nilai dan adanya hal yang dinilai. Kriterianya adalah kebijakan pendidikan yang merupakan manifestasi paradigma baru. Dengan kata lain, kebijakan pendidikan yang merupakan manifestasi paradigma baru itu menjadi titik tolak implementasinya, sekaligus sebagai cermin untuk membuat refleksi. Sedangkan hal yang dinilai atau bahan yang direfleksi adalah proses implementasi kebijakan pendidikan di Kota Salatiga menyangkut fokus masalah yang diteliti, dan hasil serta dampak dari kebijakan pendidikan yang diimplementasikan.

Sesuai fokus masalah yang diteliti, penelitian ini menggunakan pendekatan kualitatif dan kuantitatif. Data penelitian diperoleh dari informan-informan kunci serta berbagai dokumen terkait melalui studi dokumen, observasi, wawancara, dan angket.
Mengenai siapa informan-informan kunci yang dijadikan sebagai subjek penelitian, ditentukan dengan menggunakan teknik snowball sampling. Teknik snowball sampling adalah teknik pengambilan sumber data, yang pada awalnya berjumlah sedikit, lama-lama menjadi besar. Hal ini dilakukan karena dari jumlah sumber data yang sedikit itu belum mampu memberikan data yang lengkap, maka peneliti mencari aktor atau orang lain lagi yang dapat digunakan sebagai sumber data. Dengan demikian jumlah sumber data akan semakin besar dalam upaya untuk mendapatkan informasi yang maksimum.

Mengenai siapa "aktor" yang menjadi informan kunci, ditentukan dengan memilih warga sekolah yang dianggap paling mengetahui masalah yang sedang diteliti, dan pilihannya dapat terus berkembang sesuai dengan kebutuhan dan kemantapan peneliti dalam mengumpulkan data di lapangan.

Penelitian dilaksanakan di Kota Salatiga pada tahun pelajaran 2009/2010 dan 2010/2011, difokuskan di Gugus Yos Sudarso sebagai salah satu gugus dari sebanyak 15 gugus sekolah di Kota Salatiga. Penelitian difokuskan pada 3 (tiga) SD dalam gugus tersebut, yaitu 1 SD Inti dan 2 SD Imbas (negeri dan swasta). Ketiga SD tersebut, relatif merupakan SD yang memiliki prestasi akademik dan non-akademik tinggi, yang dapat sebagai representasi pendidikan di Kota Salatiga untuk bahan refleksi. Hal ini tercermin dari nilai rata-rata hasil UN yang termasuk tinggi, banyak mewakili berbagai lomba, dan memenangkan kejuaraan. Meskipun demikian, sama seperti SD lain pada umumnya, dari hasil observasi SD-SD tersebut belum banyak mengalami perubahan sebagai dampak diterapkannya paradigma baru pendidikan sebagaimana ditegaskan dalam UU Sisdiknas, yang berlaku baik untuk sekolah negeri maupun swasta.

Data yang terkumpul dianalisis secara kualitatif dengan menggunakan pendekatan induktif, sedangkan data kuantitatif digunakan sebagai suplement dan complement yang bersifat mendukung atau memperjelas. Hasil analisis tersebut direfleksi lebih lanjut melalui upaya pemaknaan menggunakan berbagai teori yang relevan, sehingga penyimpulan, pengembangan implikasi dan rekomendasi dapat diberikan. 


\section{HASIL PENELITIAN DAN PEMBAHASAN}

\section{Peran Kepala Sekolah}

Dari hasil angket menunjukkan adanya pola dan variasi peran kepala sekolah dalam peningkatan mutu sekolah. Peran kepala sekolah di SD Inti dalam aspek kepemimpinan, manajerial, dan supervisi lebih optimal jika dibandingkan dengan kedua SD Imbas. Di SD tersebut, kepala sekolah dinilai oleh para guru telah melaksanakan semua perannya lebih optimal dibandingkan kedua SD lainnya. Di samping pendekatan formal, pendekatan informal melalui bincang-bincang, diskusidiskusi kecil saat istirahat/tidak mengajar, juga banyak digunakan kepala sekolah dalam menggerakkan warga sekolah untuk berperan serta dalam meningkatkan mutu sekolah. Cara lainnya adalah dengan memberdayakan komite sekolah, orang tua, dan tokoh masyarakat. Oleh semua guru (100\%) kepala sekolah juga dinilai banyak memberikan contoh langsung dan mampu menggerakkan semangat guru, staf dan siswa dalam penca-paian tujuan sekolah. Kepala sekolah juga dapat menciptakan iklim sekolah yang baik untuk meningkatkan mutu.

Sementara itu, di kedua SD Imbas (negeri dan swasta) peran kepala sekolah kurang optimal, dibuktikan dengan peran yang lebih tersebar, dengan presentase dan intensitas yang cenderung rendah jika dibandingkan dengan SDN Inti. Hasil angket juga menunjukkan adanya perbedaan peran kepala sekolah di kedua SD Imbas. Dibandingkan dengan SDN Imbas, peran kepala sekolah di SD Swasta lebih kuat pada aspek kiat-kiat untuk memajukan sekolah, melaksanakan tugas-tugas administrasi, dan melaksanakan supervisi kerja guru, namun lebih lemah pada aspek penciptaan suasana sekolah yang akrab dan pemberian bimbingan kepada guru. Lain dari itu, di SDN Imbas apa-apa diputuskan sendiri oleh kepala sekolah. Sebagian besar guru $(64 \%)$ menyatakan bahwa kepala sekolah kurang mampu menggerakkan semangat guru, staf dan siswa dalam pencapaian tujuan sekolah. Kepala sekolah juga kurang dapat menciptakan iklim sekolah yang baik untuk meningkatkan mutu. Sedangkan di SD Swasta, pendekatan formal sangat dominan digunakan kepala sekolah baik dengan cara pembagian job/tugas di dalam raker guru maupun dengan mengadakan pembinaan rutin kepada guru setiap sabtu, dan melakukan supervisi dan controlling terhadap administrasi pembelajaran. Kepala sekolah juga dinilai oleh sebagian besar guru (79\%) mampu menggerakkan semangat guru/staf dan siswa dalam mencapai tujuan sekolah dan dalam menciptakan iklim sekolah yang baik untuk peningkatan mutu.

Menurut persepsi kepala sekolah, sejak berlakunya otonomi daerah dengan paradigma baru yang mendasarinya, telah terjadi perubahan peran kepala sekolah. Kepala sekolah menjadi lebih otonom untuk mengembangkan sekolah, dengan memanfaatkan sumber daya yang dimiliki dan mengembangkan strategistrategi peningkatan mutu berbasis sekolah sesuai dengan kondisi setempat. Meskipun demikian, di ketiga SD yang diteliti, ada polapola perubahan peran kepala sekolah yang beragam sebagai dampak paradigma baru pendidikan. Di kedua SDN, perubahan peran tersebut dipandang sebagai kesempatan untuk mewujudkan visi, ide, gagasan, keinginan dan harapan secara luas. Namun, di pihak lain, adanya perubahan peran tersebut membuat beban kerja kepala sekolah menjadi semakin berat. Peran kepala sekolah, kata mereka, lalu menjadi seperti manusia super (superman) yang harus menguasai dan sanggup melakukan banyak hal. Sementara itu, di SD swasta, perubahan peran tersebut memang membuat beban kerja kepala sekolah semakin besar, namun tidak menjadi persoalan karena sebagai sekolah swasta sudah biasa mengelola sekolah secara mandiri.

Lain dari itu, dari wawancara dengan ketiga kepala sekolah, diperoleh informasi adanya hambatan-hambatan bagi berperannya kepala sekolah dalam peningkatan mutu sekolah, yaitu: pertama, kebijakan berlakunya KTSP sekaligus dilaksanakannya Ujian Nasional. Secara ideal, berlakunya KTSP lebih menuntut perlunya peningkatan kualitas proses pembelajaran, sementara dilaksanakannya Ujian Nasional lebih mengkondisikan sekolah untuk berorientasi pada hasil, sehingga kepala sekolah cenderung berorientasi pada hasil, bukan pada peningkatan kualitas proses pembelajaran sebagaimana dikehendaki KTSP.

Kedua, beban kerja kepala sekolah yang berlebih. Era otonomi daerah memang memberi otonomi lebih besar kepada kepala sekolah untuk mengatur sekolahnya. Namun, dengan pemberian otonomi tersebut beban 
kerja kepala sekolah menjadi berlebih, terutama untuk menangani hal-hal yang berkaitan dengan urusan administratif, seperti laporan keuangan, rapat-rapat, pertemuan-pertemuan, dan sejenisnya yang menyita sebagian besar waktu, sehingga kepala sekolah cenderung mengesampingkan upaya peningkatan mutu sekolah. Kata seorang kepala sekolah, yang penting "urusan birokrasi beres, soal mutu nanti". Kepala sekolah tersebut mengungkapkan sebagai berikut.

Urusan birokrasi lebih menonjol daripada urusan peningkatan mutu. Pertemuan KKKS dan rapat-rapat Dinas diadakan lebih banyak membicarakan hal-hal yang terkait dengan urusan birokrasi, tetapi bukan bagaimana membuat sekolah menjadi lebih berkualitas. Dampak yang dirasakan kepala sekolah, kepala sekolah memang sibuk, tetapi tidak berorientasi pada mutu, mutu berjalan di tempat, waktunya lebih banyak untuk memenuhi tuntutan birokrasi.

Ketiga, bekal untuk menjadi kepala sekolah kurang. Kepala sekolah bekerja secara naluri. Umumnya, kepala sekolah tidak didesain menguasai akuntansi, misalnya, sehingga hal yang sebenarnya dapat dilakukan dengan mudah, menjadi sulit. Seorang kepala sekolah menyatakan "kesempatan kepala sekolah untuk meningkatkan profesionalitas guru sangat terbatas, karena pekerjaannya lebih terfokus ke hal-hal lain yang lebih bersifat non teknis edukatif. Sementara hal-hal yang terkait dengan peningkatan mutu, kurang mendapat perhatian". Keempat, aparat birokrasi yang mengurusi pendidikan, tidak berkompeten di bidang pendidikan. Aparat birokrasi yang diangkat menjadi kepala Dinas Pendidikan, misalnya, bukan berasal dari yang berlatar belakang pendidikan dan secara riel berprestasi, namun lebih karena selera pihak yang berkuasa.

Di kedua SDN, ada sejumlah faktor mengapa perubahan peran tersebut dirasakan sebagai beban. Di samping dipengaruhi oleh kemampuan kepala sekolah untuk memahami perubahan yang terjadi dan implikasinya, juga tergantung dari kapasitas dan kesiapannya dalam menjalankan peran-peran baru yang dituntut oleh era otonomi. Jika pemberian otonomi kepada sekolah dan kepala sekolah tidak disertai dengan pengembangan kapasitas kepala sekolah secara memadai, maka peranperan baru tersebut akan menjadi beban tambahan bagi kepala sekolah. Lebih-lebih, kepala sekolah yang aktif sekarang, dulunya tidak dididik dan didesain untuk menjalankan peran-peran baru tersebut, seperti peran manajerial/kepemimpinan, dan lainnya. Dengan demikian, pemberian otonomi yang lebih besar disertai dengan pengembangan kapasitas kepemimpinan/manajerial kepala sekolah, menjadi salah satu jalan keluar yang mutlak perlu dilakukan.

Menurut Bank Dunia (1998), peningkatan mutu sekolah memerlukan kepala sekolah yang mampu: (a) menjabarkan sumber daya yang ada untuk menyediakan dukungan yang memadai bagi guru, bahan pengajaran yang cukup, dan pemeliharaan fasilitas yang baik; (b) memberikan waktu yang cukup untuk pengelolaan dan pengorganisasian proses instruksional; dan (c) berkomunikasi secara teratur dengan staf, orang tua, siswa, dan masyarakat terkait. Sementara, pada era sebelum otonomi, kepala sekolah negeri memiliki otonomi yang terbatas dalam mengelola sekolah dan mengalokasikan sumber daya yang diperlukan. Kebanyakan kepala sekolah juga tidak dilengkapi dengan kemampuan manajerial atau kepemimpinan yang memadai. Banyak di antara kepala sekolah yang hanya mengikuti pelatihan beberapa hari tentang teori-teori administrasi dan orientasi peraturan dan kebijakan pendidikan ketika mereka mulai menjabat sebagai kepala sekolah. Dengan kata lain, kemampuan kepala sekolah negeri belum memenuhi persyaratan mutu untuk meningkatkan efektivitas manajemen sekolah. Kondisi ini semakin menyulitkan kepala sekolah, karena seperti sudah ditegaskan di depan, sekolah negeri umumnya juga tidak memiliki otonomi yang memadai untuk meningkatkan mutu sekolah.

Selain itu, pengangkatan kepala sekolah belum didasarkan atas prestasi kerja, dan masih lebih banyak berdasarkan urutan kepangkatan. Oleh karena itu, mestinya, pemberian otonomi yang lebih besar kepada kepala sekolah, harus diikuti dengan pemilihan kepala sekolah yang baik yang memiliki ketrampilan dan karakteristik yang diperlukan untuk sekolah yang bernuansa otonomi, pemberian penghargaan terhadap kepala sekolah yang baik dan mengganti mereka yang kurang baik, dan pengembangan ketrampilan manajemen kepa- 
la sekolah. Program-program seperti ini membantu kepala sekolah untuk memahami aspekaspek di luar peranan administrasi mereka yang kemudian dapat meningkatkan mutu kepemimpinan pendidikan (Bank, 2001, p.157).

Di Salatiga sendiri, dari segi sistem seleksi yang sekarang sudah disahkan, sebenarnya telah mengakomodasi jiwa dan semangat paradigma baru pendidikan dan syarat-syarat yang diperlukan bagi seorang kepala sekolah untuk sekolah yang bernuansa otonomi, seperti berprestasi, kreatif, inovatif, memiliki komitmen untuk mencapai tujuan pendidikan, dan sejenisnya. Namun, pada tingkat praksis, sistem seperti itu tidak selalu berjalan seperti yang diharapkan, karena masih ada ruangruang proses seleksi yang tidak transparan, yang tidak dapat diketahui dan dikontrol oleh masyarakat.

Menurut Kotter (1996), kepemimpinan adalah mesin yang mendorong perubahan (the engine that drives change), lebih-lebih dalam masyarakat yang berubah dengan cepat. Begitu juga dengan fenomena kepala sekolah sesudah otonomi, kepala sekolah memiliki otonomi yang lebih besar untuk mengelola dan menggerakkan perubahan di sekolah. Tetapi, obyek pengelolaan kepala sekolah tersebut demikian luasnya dan lebih banyak pada tugas-tugas yang sifatnya administratif, sehingga otonomi lebih besar yang dimiliki tidak dapat digunakan untuk memikirkan bagaimana meningkatkan mutu sekolah, tetapi terdesak oleh berbagai pekerjaan administratif yang lebih mendesak. Mesin kepemimpinan kepala sekolah, meminjam istilah John Kotter, tidak dapat dipakai untuk mendorong perubahan di tingkat sekolah, tetapi justru habis untuk menyelesaikan tugas-tugas di luar akademik.

Pemberian otonomi kepada sekolah mestinya disertai pemberian kepercayaan kepada sekolah, dukungan sumber daya pendukung untuk melakukan otonomi itu, dan kualitas serta topangan aparat birokrasi pendidikan, sehingga sekolah lebih berkonsentrasi pada upaya peningkatan mutu sekolah. Bila tidak, maksud pemberian otonomi agar kepala sekolah lebih mampu meningkatkan mutu akan cenderung gagal total. Ini sesuai dengan pendapat Peach (1994), yang disepakati oleh Cranston (1993) dan Rizvi (1994), yang menyatakan bahwa yang utama dari otonomi sekolah adalah peningkatan manaje- men sekolah untuk pengalokasian sumber daya ke kepentingan-kepentingan yang lebih bersifat edukatif (Fasli Jalal \& Dedi Supriadi, 2001, p.159). Lagi pula, pemberian otonomi tersebut tidak akan menyelesaikan semua persoalan pendidikan, bahkan mungkin dapat menimbulkan masalah baru sepanjang kriteria yang ditetapkan tidak dilaksanakan sebagaimana seharusnya.

\section{Peningkatan Profesionalisme Guru}

Di Kota Salatiga, peningkatan profesionalitas guru sudah menjadi prioritas kebijakan dan sistem pelaksanaannya sudah mendasarkan pada paradigma baru pendidikan. Hal ini dibuktikan dari berbagai dokumen perencanaan daerah yang selalu menyatakan bahwa kebijakan fungsi pendidikan di Kota Salatiga diarahkan pada "upaya-upaya pemenuhan pelayanan dasar dalam rangka pengembangan SDM yang berkualitas melalui peningkatan profesionalisme".

Kebijakan peningkatan profesionalitas guru di Kota Salatiga dilakukan melalui peningkatan mutu pendidik dan tenaga kependidikan, yang program-programnya apabila direfleksi dan dipetakan terkait dengan tiga kata kunci, yaitu peningkatan kualifikasi, kompetensi, dan pendidikan keprofesian. Pada tingkat praksis, program-program tersebut diimplementasikan oleh sekolah/guru. Sekolah/ guru dapat sebagai peserta kegiatan yang diadakan oleh Dinas Pendidikan dan atau lembaga penyelenggara yang lain, namun dapat pula merumuskan kebijakan-kebijakan sekolah yang lebih operasional sifatnya.

Praksis peningkatan profesionalitas guru pada aspek peningkatan kualifikasi akademik, tampak ada kesenjangan dengan kebijakan yang dibuat, dalam arti yang terjadi tidak seperti yang diharapkan dalam kebijakan. Meskipun sebagian besar guru di tiga SD ingin meningkatkan kualifikasi sebagai guru SD, namun dalam realitas tidak banyak yang mau menggunakan kesempatan tersebut, dengan alasan yang beragam. Dari hasil wawancara diketahui, bahwa kebijakan peningkatan kualifikasi akademik tidak disertai dengan bantuan pembiayaan, tidak seperti yang diwajibkan dalam pasal 42 ayat 5 (Perda, 2009), juga tidak disertai sosialisasi, himbauan dan pemberian motivasi. Sebagian guru yang ingin meningkatkan kualifikasi, kurang mendapat dukungan dari sekolah dan birokrasi, baik 
dukungan finansial maupun motivasional. Padahal, dukungan sekolah dan birokrasi pendidikan utamanya sangat penting untuk meningkatkan kualifikasi akademik, sebagai salah satu unsur penunjang profesionalisme guru. Praktis, keikutsertaan seorang guru dalam mengikuti program peningkatan kualifikasi adalah lebih karena prakarsa dan inisiatif guru itu sendiri.

Dari sudut peningkatan kompetensi guru, strategi yang digunakan masih menggunakan strategi pengembangan yang tradisional. Pengembangan profesional yang tradisionil dilakukan tanpa bantuan multimedia, diawali dengan menyelenggarakan pelatihan untuk calon pelatih. Pelatih yang dihasilkan kemudian melatih para guru, selanjutnya guru memanfaatkan hasil pelatihan tersebut untuk mendidik para siswa. Pada proses setiap tahap, informasi yang diberikan cenderung berkurang atau semakin membingungkan, sehingga informasi yang diperoleh siswa cenderung lemah, telah mengalami transformasi dari informasi awal.

Lain dari itu, Cranton (1996, p.26) mengemukakan berbagai bentuk strategi pengembangan profesional tradisionil yang umum digunakan, seperti manuals, guides, newsletters, how-to materials, workshops, retreats, training programs, dan evaluations and performance appraisals. Menurutnya, penggunaan strategi semacam itu kurang dapat meningkatkan profesionalitas guru, membuat guru senantiasa tergantung pada pihak lain, dan tidak menumbuhkan sifat kemandirian dari guru sebagai subyek yang dewasa. Ia kemudian menawarkan tiga konsep sentral di dalam teori pendidikan orang dewasa, yang dipandang tepat untuk pengembangan profesional guru, yaitu self-directed learning, critical reflection, dan transformative learning. Ketiganya sebagai satu konsep utuh, saling berkaitan dan melengkapi. Baginya, pengembangan profesional merupakan proses belajar transformatif bagi orang dewasa. Selfdirected learning merupakan fondasi dari transformatif learning, sedangkan critical reflection merupakan proses sentral yang diperlukan dalam transformative learning. Selfdirected learning sebagai proses transformatif dapat dikembangkan dengan melakukan refleksi kritis secara terus-menerus baik terhadap isi maupun proses. Pengembangan selfdirected learning juga harus memperhatikan perbedaan-perbedaan individual para pendidik, terutama tipe psikologis mereka.

Mengenai dampak dari implementasi kebijakan peningkatan profesionalitas guru, dirasakan beragam oleh para guru. Pengembangan profesionalitas guru belum diikuti secara merata oleh semua guru, dilakukan secara sporadik (tidak berkelanjutan), dan belum diikuti monitoring dan evaluasi yang sistematik dan terencana. Materi pengembangannya cenderung masih diwarnai usaha penyeragaman pola dan materi, tanpa memperhatikan kebutuhan spesifik guru dan sekolah. Dampaknya dirasakan beragam oleh guru. Sebagian guru menyatakan bahwa program peningkatan profesionalitas guru semacam itu, berdampak pada kinerja guru namun bersifat sementara. Dampak tersebut hanya terjadi pada awal-awal sesudah mengikuti kegiatan, dan ketika disupervisi, namun dalam perkembangannya guru akan kembali ke pola lama.

Dari hasil pembahasan tersebut, jelas bahwa dari segi sistem kebijakan peningkatan profesionalitas guru di tingkat Kota Salatiga, telah ada upaya secara konsisten untuk mewujudkan paradigma baru pendidikan pascareformasi, hanya pada tingkat praksis pendidikan, program-program peningkatan profesionalitas guru tersebut masih menggunakan strategi tradisionil, direspon secara beragam oleh guru, dan menimbulkan dampak terhadap kinerja guru yang beragam pula. Dalam era otonomi daerah dengan paradigma baru pendidik yang menyertainya, pengembangan profesionalitas guru mengalami perubahan dan peningkatan. Perubahan dan peningkatan terjadi dari segi keragaman dan kesempatan untuk mengikuti program profesionalitas guru. Namun demikian, perubahan yang ada bukan terjadi karena adanya kesadaran internal, tetapi karena digerakkan oleh pihak luar.

\section{Proses Pembelajaran}

Dari segi sistem, di Kota Salatiga ada semangat untuk mengimplementasikan paradigma baru dalam proses pendidikan dengan menjunjung tinggi nilai-nilai demokrasi. Cara pembuatan Perda tentang penyelenggaraan pendidikan sebagai kebijakan operasional yang mengatur tentang proses pendidikan tersebut, misalnya, dibuat secara bottom-up, demokratis, dan partisipatif, serta mendasarkan pada paradigma baru pendidikan yang tercantum dalam UU Sisdiknas dan prinsip- 
prinsip good governance. Dari segi substansinya, dalam Perda tersebut juga diatur mengenai konsep pendidikan dan bagaimana pendidikan itu diselenggarakan, yang jelas sesuai dengan kebijakan-kebijakan pendidikan yang merupakan manifestasi paradigma baru pendidikan.

Dalam hal kurikulum, ketiga sekolah sudah menetapkan KTSP dan membuat silabus sesuai dengan kemampuan sekolah, namun ada variasi-variasi di antara ketiga SD. Pada kedua SDN, silabus relatif bersifat umum/ egaliter dan substansinya sama dengan standar isi, sehingga terkesan sebagai standar baku, bukan standar minimal sebagaimana dikehendaki dalam kebijakan. Sementara itu, di SD Swasta, KTSP sangat bernuansa agama Islam. Nilai-nilai agama Islam dirancang mendasari setiap penyajian kompetensi dasar. Ditegaskan, "kepala sekolah dan guru dapat mengembangkan indikator sesuai dengan kemampuan sekolah dan menyesuaikan dengan kebijakan pemerintah setempat" (Dokumen silabus, 2007). Dengan demikian, apa yang terjadi di SD Swasta sesuai dan merupakan implementasi dari pasal 55 UU Sisdiknas, yang menyebutkan bahwa "masyarakat berhak menyelenggarakan pendidikan...sesuai dengan kekhasan agama..."; "kekhasan satuan pendidikan yang diselenggarakan masyarakat tetap dihargai dan dijamin" (penjelasan pasal 55 UU Sisdiknas). Dalam pasal 33 ayat 5 Perda (2009) juga dinyatakan bahwa "satuan pendidikan yang dilaksanakan oleh masyarakat dapat menambah materi pembelajaran sesuai dengan ciri khas masing-masing".

Mengenai orientasi pendidikannya, ketiga sekolah mengarahkan ketercapainya Standar Kompetensi Lulusan, yang secara substansial mencakup baik peningkatan kualitas akademik maupun nonakademik (Renstra Disdikpora, 2009-2012). Menurut persepsi para guru, kedua jenis prestasi tersebut sama-sama penting, meskipun demikian mereka menyadari bahwa dalam kenyataan sekolah/guru cenderung menekankan prestasi akademik (Armstrong, 2006). Sementara itu, mengenai RPP yang merupakan penjabaran dari silabus, dari segi komponennya ketiga sekolah sama. Namun, dari segi substansinya, ada perbedaan sebagai konsekuensi dari perbedaan substansi silabus yang dibuat sekolah/ guru. Pada SD Swasta, umumnya sengaja dikaitkan dengan bunyi ayat-ayat Al Quran dan Hadist, tidak demikian halnya di kedua SDN.

Pada tingkat pelaksanaan, khususnya mengenai persyaratan jumlah siswa, di kedua SDN menyimpang dari sistem yang diatur oleh Dinas pendidikan. Dinas pendidikan mengatur bahwa jumlah siswa dalam setiap kelas untuk sekolah yang berstatus bukan SSN maksimum 40 siswa, sementara kedua SDN tersebut menerima jauh melebihi 40 siswa untuk setiap kelas. Ini berbeda dengan SD Swasta, yang menentukan jumlah siswa untuk setiap kelas adalah minimum 30 siswa, namun tak melebihi 40 siswa. Selain itu, beban kerja minimal guru sebanyak 24 jam/minggu dapat terpenuhi di ketiga SD, kecuali guru non PNS di sekolah negeri dan guru bahasa Inggris di SD Swasta. Penentuan buku pelajaran di ketiga sekolah, tanpa pertimbangan dari komite sekolah, tidak seperti yang diharapkan dalam kebijakan.

Sedangkan berkenaan dengan pelaksanaan pembelajaran itu sendiri, ada pola-pola proses pendidikan yang sama dan bervariasi di ketiga SD. Pada kegiatan pendahuluan, yang paling banyak dilakukan adalah menyiapkan peserta didik secara psikhis, dengan cara yang sangat bervariasi. Di SD Swasta, hampir sama dengan kedua SDN, namun satu hal yang membedakan adalah bahwa di SD Swasta, kegiatan pendahuluan yang bernuansa Islami sangat dominan, misalnya dengan tadarus (membaca ayat Al'quran) untuk menenangkan siswa, dilanjutkan dengan melantunkan "Asmaul husna" (melantunkan Asma Allah yang indah). Dengan demikian, meskipun terdapat begitu banyak kesamaan di antara ketiga SD, namun khusus di SD Swasta, kegiatan yang bernuansa Islami sangat dominan.

Pada kegiatan inti, khususnya pada proses eksplorasi, hasil angket menunjukkan bahwa sebagian besar guru di tiga SD $(80,3 \%)$ melibatkan peserta didik secara aktif dalam pembelajaran. Dengan presentase dan frekuensi yang beragam, sebagian besar guru juga melakukan berbagai aspek kegiatan eksplorasi yang dituntut dalam standar proses. Pola variasi kegiatan eksplorasi di antara ketiga $\mathrm{SD}$, bukan terletak pada ragam kegiatan eksplorasi yang dilakukan, tetapi lebih pada urutan kegiatan eksplorasi yang dilakukan, berdasarkan presentase dan intensitasnya. Dalam hal ini, di kedua SDN relatif sama, tidak demikian halnya di SD Swasta. 
Pada proses elaborasi, sebagian besar guru di tiga SD selalu memfasilitasi peserta didik untuk berkompetisi secara sehat $(58,2 \%)$, dan memberi kesempatan untuk berfikir, menganalisis, menyelesaikan masalah dan bertindak tanpa rasa takut $(56,4 \%)$. Sebagian besar guru juga sering memfasilitasi peserta didik membuat laporan pengerjaan tugas $(51,1 \%)$, dan membiasakan mereka membaca dan menulis melalui tugas-tugas tertentu.

Pada proses konfirmasi, hasil angket menunjukkan bahwa sebagian besar guru di ketiga SD selalu menjawab pertanyaan peserta didik yang menghadapi kesulitan $(88,1 \%)$. Sementara itu, hasil observasi ketiga SD menunjukkan hal yang relatif berbeda dengan hasil angket, baik pada kegiatan eksplorasi, elaborasi maupun konfirmasi. Jika data hasil angket menunjukkan bahwa guru melakukan semua indikator aktivitas eksplorasi, elaborasi dan konfirmasi, tidak demikian halnya yang tercermin dari data hasil observasi. Proses pembelajaran kadang memang menunjukkan terjadinya ketiga proses tersebut, namun jelas tidak selengkap indikator kegiatan eksplorasi, elaborasi dan konfirmasi yang dituntut dalam standar proses.

Mengapa terjadi demikian, banyak faktor yang terkait. Di samping, mungkin, "terkondisi oleh instrumen", seperti ada keharusan untuk memberikan jawaban, dari RPP, hasil wawancara dengan para guru, dan hasil FGD yang sengaja diadakan, diketahui bahwa proses pembelajaran oleh semua guru di tiga SD tidak dirancang dan dilaksanakan melalui ketiga tahap tersebut. Hasil wawancara juga menunjukkan bahwa guru belum memahami mengenai macam, pengertian, dan kaitan ketiga istilah dalam kegiatan inti tersebut. Dengan demikian, yang lebih tercermin dalam RPP dan proses pembelajaran adalah ketika guru memasuki kegiatan inti, guru langsung masuk ke tahap penutup pembelajaran. Guru tidak memilah kegiatan inti ke dalam tiga tahap proses pembelajaran tersebut. Pada umumnya, mereka berargumen bahwa meskipun standar proses sudah disosialisasikan, namun belum diikuti oleh semua guru. Sosialisasi yang terjadi selama ini hanya melibatkan guru-guru tertentu saja, namun tidak atau belum ditindaklanjuti dengan sosialisasi ke semua guru. Akibatnya, meskipun guru mengetahui adanya standar proses tersebut, mereka belum cukup memahami isinya. Hal ini menjadi alasan, mengapa yang kemudian terjadi praksis proses pendidikan di ketiga SD tersebut, belum cukup sesuai dengan yang dikehendaki dalam standar proses pembelajaran.

Dari segi orientasi pembelajaran, pembelajaran masih cenderung menggunakan pola lama. Paradigma pembelajaran yang behavioristik masih sangat kuat, sedangkan bentuk-bentuk keaktifan siswa yang muncul bukan cerminan dari diterapkannya paradigma konstruktivistik dalam pembelajaran, tetapi lebih sebagai respons atas stimulus yang diberikan guru. Intensitas keaktifan siswa tersebut dengan demikian tergantung pada kualitas dan variasi stimulus yang dibuat guru. Perbedaan antar guru dalam proses pembelajaran, lebih banyak ditentukan oleh kemampuan guru dalam membuat variasi stimulus, dan bukan karena menerapkan paradigma konstruktivistik dalam pendidikan. Dengan demikian, pembelajaran masih cenderung bernuansa ekspository (guru menjelaskan, murid mendengarkan). Guru masih menggunakan paradigma pengajaran yang teacher oriented, belum terjadi pergeseran paradigma proses pendidikan, dari paradigma pengajaran ke paradigma pembelajaran yang konstruktivistik.

Dalam hal pendidikan nilai, tampak ada pola-pola yang beragam dalam cara penanaman nilai melalui proses pembelajaran. Di kedua SDN, pendidikan nilai cenderung terjadi secara tidak terencana, atau secara spontan sebagai respons atas perilaku siswa yang negatif, dan bukan merupakan usaha sadar dan terencana. Berbeda dengan itu, di SD Swasta pendidikan nilai, terutama nilai iman dan taqwa, secara sadar dirancang dalam silabus dan RPP, meskipun dalam praktek penanaman nilai secara spontan juga terjadi. Dari hasil analisis RPP, hasil observasi, dilengkapi dengan hasil wawancara, tampak bahwa nilai-nilai yang ditanamkan pada peserta didik amat beragam. Selain tergantung pada mata pelajaran dan kompetensi dasar yang diajarkan, nilai-nilai yang ditanamkan juga dipengaruhi oleh jenis stimulus berupa perilaku peserta didik dan tingkatan kelas.

Sebagai usaha pendidikan, penanaman sikap dan nilai hidup merupakan proses, maka mestinya dapat diberikan melalui pendidikan formal dengan direncanakan dan dirancang 
secara matang (Suparno, 2002, p.62). Direncanakan dan dirancang tentang nilai-nilai apa saja yang akan diperkenalkan, dan metode serta kegiatan apa yang dapat digunakan untuk menanamkan nilai-nilai tersebut. Nilainilai yang akan ditawarkan dan ditanamkan kepada siswa harus dilaksanakan secara bertahap sesuai dengan tugas dan perkembangan kejiwaan anak. Lickona (2013, p.75), menekankan pentingnya diperhatikan tiga unsur dalam menanamkan nilai moral supaya berhasil, yaitu unsur pengertian, perasaan, dan tindakan moral. Keiga unsur itu saling berkaitan. Ketiga unsur itu perlu diperhatikan, supaya nilai yang ditanamkan tidak tinggal sebagai pengetahuan saja tetapi sungguh menjadi tindakan seseorang. Menurut Muhadjir (1997), "seseorang bisa disebut pendidik apabila seseorang tersebut disamping memiliki pengetahuan lebih, juga mampu mengimplisitkan nilai dalam pengetahuan itu dan bersedia menularkan pengetahuan beserta nilainya kepada orang lain". Sementara menurut Depdiknas (2003), proses pembelajaran harus dilandasi oleh prinsip "mengembangkan beragam kemampuan yang bermuatan nilai". Manusia adalah penghayat nilai, kata Koesoema (2012, p.49), seperti halnya peserta didik, yang hidup, tumbuh, dan berkembang dalam suatu komunitas, sehingga mereka perlu dibekali bukan hanya pengetahuan, tetapi juga nilai-nilai dan sikap-sikap hidup yang dianut dan diyakini masyarakatnya. Tujuan pendidikan nilai, menurut UNESCO (1994), meliputi tindakan mendidik yang berlangsung mulai dari usaha penyadaran nilai sampai pada perwujudan perilaku-perilaku yang bernilai.

Dari segi sistem penilaian, sebagian besar guru menggunakan teknik tes, teknik non tes jarang digunakan. Sementara itu, bentuk penilaian portofolio yang diidealkan dalam penerapan KTSP, pada awalnya diterapkan oleh sebagian besar guru, namun dalam perkembangannya guru kembali ke pola lama. Kekecualian terjadi di SD Swasta, yang sebagian besar gurunya masih tetap menggunakan bentuk penilaian portofolio dalam pembelajarannya. Hal ini terjadi karena segera sesudah sistem penilaian portofolio itu diterapkan, pihak yayasan melakukan monitoring dan evaluasi berkelanjutan secara berkala, di samping selalu ada pembinaan oleh kepala sekolah kepada para guru setiap hari sabtu.

\section{SIMPULAN}

\section{Simpulan}

Berdasarkan hasil penelitian dan pembahasan di atas, maka simpulan penelitian ini adalah sebagai berikut.

\section{Peran Kepala Sekolah}

Ada pola dan variasi peran kepala sekolah dalam peningkatan mutu sekolah. Peran kepala sekolah di SD Inti dalam aspek kepemimpinan, manajerial, dan supervisi, lebih optimal jika dibandingkan dengan kedua SD Imbas. Di kedua SD Imbas, dibandingkan dengan SDN Imbas, peran kepala sekolah di SD swasta lebih kuat pada aspek kiat-kiat untuk memajukan sekolah, melaksanakan tugas-tugas administrasi, dan melaksanakan supervisi kerja guru, namun lebih lemah pada aspek penciptaan suasana sekolah yang akrab dan pemberian bimbingan kepada guru.

Dengan berlakunya paradigma baru pendidikan, peran kepala sekolah mengalami perubahan. Kepala sekolah menjadi lebih otonom untuk mengembangkan kreativitasnya dalam rangka meningkatkan mutu sekolah. Dengan perubahan peran tersebut beban kerja kepala sekolah menjadi semakin berat, tetapi berbeda dengan kedua SDN, di SD swasta, perubahan peran tersebut tidak terlalu menjadi persoalan, karena sudah biasa mengelola sekolah secara mandiri.

Bagi pendidikan SD, perubahan peran kepala sekolah kurang memberi dampak pada peningkatan mutu sekolah, karena terkendala oleh sejumlah faktor, yaitu berlakunya KTSP yang lebih menekankan peningkatan kualitas proses, sementara Ujian Nasional menekankan hasil sehingga kepala sekolah cenderung berorientasi hasil, bekal menjadi kepala sekolah kurang, aparat birokrasi yang mengurusi pendidikan tidak berkompeten di bidang pendidikan, dan beban pekerjaan kepala sekolah berlebih terutama untuk menangani urusan administratif-birokrasi, sehingga kepala sekolah cenderung mengesampingkan upaya peningkatan mutu sekolah.

\section{Peningkatan Profesionalitas Guru}

Di Salatiga, peningkatan profesionalitas guru sudah menjadi prioritas kebijakan. Peningkatan profesionalitas guru dilakukan 
dengan mendasarkan pada paradigma baru pendidikan. Kebijakan peningkatan profesionalitas guru dilakukan melalui peningkatan mutu pendidik, terfokus pada upaya peningkatan kualifikasi akademik, kompetensi, dan pendidikan keprofesian. Strategi pengembangan profesionalitas guru masih bersifat tradisionil.

Dengan berlakunya paradigma baru pendidikan, ada perubahan dan peningkatan dari segi keragaman dan kesempatan untuk mengikuti program profesionalitas guru, namun implementasinya belum optimal. Peningkatan profesionalitas guru belum diikuti secara merata oleh semua guru, masih dilakukan secara sporadik (tidak berkelanjutan), dan belum dilakukan monitoring dan evaluasi yang sistematik dan terencana. Materi pengembangannya cenderung masih diwarnai usaha penyeragaman pola dan materi, tanpa memperhatikan kebutuhan spesifik guru dan sekolah.

Implementasi program peningkatan profesionalitas guru berdampak pada kinerja guru namun bersifat sementara. Dampak tersebut hanya terjadi pada awal-awal sesudah mengikuti kegiatan dan ketika disupervisi, namun dalam perkembangan lebih lanjut guru kembali ke pola lama. Di samping itu, kesempatan kepala sekolah untuk meningkatkan profesionalitas guru sangat terbatas, karena pekerjaannya lebih terfokus ke pekerjaan yang lebih bersifat administratif, sehingga hal-hal yang terkait dengan peningkatan profesionalitas guru kurang mendapat perhatian.

\section{Proses Pembelajaran}

Sistem penyelenggaraan pendidikan yang mengatur tentang proses pendidikan telah mendasarkan pada paradigma baru pendidikan dan prinsip-prinsip good governance. Dengan diterapkannya paradigma baru pendidikan, proses pembelajaran di ketiga SD mengalami perubahan. Perubahan terjadi pada perangkat pembelajaran, namun ada variasi isi dan corak dari perangkat pembelajaran tersebut. Di kedua SDN, perangkat pembelajaran bersifat umum/egaliter, sedangkan di SD Swasta, sangat bernuansa afiliasi agama. Nilai-nilai agama dirancang mendasari setiap penyajian kompetensi dasar.

Dari segi pelaksanaan, proses pembelajaran belum sesuai dengan standar proses. Paradigma pembelajaran yang behavioristik masih sangat kuat, sedangkan bentuk-bentuk keaktifan siswa bukan cerminan dari diterapkannya paradigma konstruktivistik dalam pembelajaran, tetapi lebih sebagai respons atas stimulus yang diberikan guru. Pembelajaran masih menggunakan paradigma pengajaran yang teacher oriented, belum terjadi pergeseran paradigma proses pendidikan, dari paradigma pengajaran ke paradigma pembelajaran yang konstruktivistik.

Dari segi pendidikan nilai, ada polapola yang beragam dalam cara penanaman nilai melalui proses pembelajaran. Di kedua SDN, penanaman nilai cenderung terjadi secara spontan sebagai respons atas perilaku siswa yang negatif. Di SD Swasta, pendidikan nilai, terutama nilai iman dan taqwa, secara sadar dirancang dalam silabus dan RPP, meskipun penanaman nilai secara spontan juga terjadi. Nilai-nilai yang ditanamkan pada siswa amat beragam, selain tergantung pada mata pelajaran dan kompetensi dasar, juga dipengaruhi oleh jenis stimulus berupa perilaku siswa yang negatif dan tingkatan kelas.

\section{Rekomendasi}

Berdasarkan simpulan, maka beberapa rekomendasi diberikan sebagai berikut.

\section{Peran Kepala Sekolah}

Kepala sekolah yang berperan dominan direkrut dari guru yang berprestasi. Oleh karena itu, sistem seleksi kepala sekolah yang sudah dibuat sesuai dengan jiwa dan semangat otonomi, perlu dilaksanakan secara konsisten dan transparan, melibatkan segenap aktor dalam setiap tahapan proses seleksi. Sistem seleksi kepala sekolah adalah sebuah kerja kolaboratif-sinergistis, sehingga berfungsinya para aktor secara optimal dan konsisten dengan sistem seleksi yang sudah dibuat, akan lebih memungkinkan ditemukannya "qualified principal" sehingga dapat berperan optimal sesuai dengan tuntutan era otonomi.

Pengembangan kapasitas dan profesionalitas kepala sekolah perlu dilakukan, dengan memberi kesempatan untuk mengikuti pendidikan dan pelatihan yang sesuai dengan kebutuhan kepala sekolah dalam era otonomi; juga menggunakan strategi yang lebih modern, yang memungkinkan kepala sekolah belajar sendiri, dengan melakukan refleksi terhadap kinerjanya, ke arah perbaikan/perubahan yang terus-menerus. 
Perlu dikembangkan teori kebijakan pendidikan yang berkenaan dengan pembuatan sistem seleksi kepala sekolah yang berkualitas, yang dilaksanakan secara konsisten oleh segenap aktornya, yang bisa menemukan "qualified principal", dan sistem pengembangan profesionalitas kepala sekolah yang mampu meningkatkan kapasitas kepala sekolah yang bersangkutan untuk menjalankan peran-peran baru sebagai konsekuensi dari tuntutan otonomi.

\section{Peningkatan Profesionalitas Guru}

Sistem penyelenggaraan pendidikan yang sudah sudah mendasarkan pada paradigma baru pendidikan, perlu diimplementasikan secara konsisten. Implementasinya perlu dirancang berkelanjutan, dengan dilakukan monitoring dan evaluasi yang sistematik dan terencana, serta memberi kesempatan ke semua guru secara merata.

Strategi pengembangan profesionalitas guru jangan hanya menggunakan strategi pengembangan yang tradisionil, tetapi menggunakan strategi lain yang memungkinkan guru untuk berkembang profesionalitasnya secara optimal dan mandiri.

Pengembangan profesionalitas guru perlu dukungan dari seorang kepala sekolah yang memiliki waktu dan kesempatan untuk melakukannya. Oleh karena itu, hal-hal yang terkait dengan peningkatan profesionalitas guru mestinya lebih mendapat perhatian, dan jangan dikalahkan oleh pekerjaan yang lebih bersifat administratif.

\section{Proses Pembelajaran}

Sistem penyelenggaraan pendidikan yang mengatur tentang proses pendidikan perlu dilaksanakan secara konsisten, sehingga perubahan yang terjadi sesuai dengan yang diharapkan dalam kebijakan. Perubahan yang terjadi bukan hanya pada perangkat pembelajarannya saja, tetapi perubahan yang substansial, berupa perubahan sikap dan perilaku guru dalam pembelajaran karena digerakkan oleh kesadaran internal.

Perlu membangun kesadaran internal dari guru bahwa jiwa standar isi adalah standar minimal yang dapat dikembangkan guru. Begitu pula standar proses dijiwai oleh paradigma pembelajaran yang konstruktivistik, yang lebih berpusat pada peserta didik (student centered). Oleh karena itu, pergeseran orientasi pembelajaran ke arah yang konstruk- tivistik dan berpusat pada siswa perlu diupayakan dan ditumbuhkan pada guru.

Proses pembelajaran, disamping memberi pengetahuan, harus pula bersifat mendidik, dalam arti menanamkan nilai-nilai tertentu, seperti memberikan keteladanan, membangun kemauan dan mengembangkan potensi dan kreatifitas peserta didik. Agar dapat disebut sebagai usaha pendidikan, pendidikan nilai itu harus merupakan usaha sadar dan terencana, bukan hanya terjadi secara spontan sebagai respon atas perilaku siswa yang negatif.

\section{DAFTAR PUSTAKA}

Cranton, P. (1996). Professional development as transformative learning. San Francisco:Jossey-BASS A. Wiley Company.

Depdiknas.(2007). Tindak lanjut tiga pilar kebijakan pendidikan nasional oleh daerah. Jakarta: Ringkasan Eksekutif Penelitian dan Inovasi Terpilih Puslitjaknov 2006.

(2007). Peningkatan mutu, relevansi, dan daya saing pendidikan. Jakarta:Puslitjaknov Balitbang Depdiknas.

.(2007). Peraturan Mendiknas RI Nomor 41, Tahun 2007, tentang Standar Proses untuk Satuan Pendidikan Dasar dan Menengah.

.(2010). Peraturan Mendiknas RI Nomor 28, Tahun 2010, tentang Penugasan Guru sebagai Kepala Sekolah.

Fiske, E.B. (1998). Desentralisasi pengajaran, politik dan konsensus. Jakarta: Penerbit P.T Gramedia Widia Sarana Indonesia.

Hadiyanto. (2004). Mencari sosok desentralisasi manajemen pendidikan Indonesia. Jakarta: Penerbit Rineka Cipta.

Jalal, F. \& Supriadi, D. (Ed.). (2001). Reformasi pendidikan dalam konteks otonomi daerah. Yogyakarta: Adicita Karya Nusa.

Joyce, B. \& Calhooun, E. (2010). Models of professional development. California: A SAGE Company. 
Koesoema, D. (2012). Pendidikan karakter utuh dan menyeluruh. Yogyakarta: Penerbit Kanisius.

Kotter, J. P. (1996). Leading change. Boston: Harvard Business School Press.

Lickona, T. (2013). Pendidikan Karakter. Bandung: Nusa Media.

Muhadjir, N. (2003). Ilmu pendidikan dan perubahan sosial. Yogyakarta: Penerbit Rake Sarasin.

Sudarsono, F.X.(1999). Paradigma baru pendidikan Indonesia dalam abad 21. Yogyakarta: Seminar Pendidikan Nasional Tahun 1999.

Sulasmono, B.S.(2004). Paradigma baru itu bernama konstruktivisme. News letter Akademia, Dewan Pendidikan Kota Salatiga, 4, 3-4.

Suparno, P., et al.(2002). Pendidikan Budi Pekerti di Sekolah. Yogyakarta: Penerbit Kanisius. . (2007). Filsafat konstruktivisme. Yogyakarta: Penerbit Kanisius.
Supriadi, D. (2003). Satuan biaya pendidikan dasar dan menengah. Bandung: Remaja Rosdakarya.

Surakhmad, W. (2009). Pendidikan nasional strategi dan tragedi. Jakarta: PT Kompas Media Nusantara.

Suyanto. (2006). Di belantara pendidikan bermoral. Yogyakarta: Unit Percetakan dan Penerbitan UNY.

Suyata. (2000). Desentralisasi dan meletakkan dasar-dasar perbaikan mutu sekolah: Dimensi pemberdayaan. Jurnal Dinamika Pendidikan, 3, 71-86.

Tilaar, H.A.R.(2004). Paradigma baru pendidikan nasional. Jakarta: Penerbit Rineka Cipta.

Undang-Undang RI Nomor 20, Tahun 2003, tentang Sistem Pendidikan Nasional.

Yin Cheong Cheng. (2002). New

paradigm of bonderless education.

Hongkong: Cen-tre for Research and International Collaboration Asia-Pacific Centre for Education Leadership and School Qua-lity Hongkong Institute of Education. 